\title{
Interfaith Dialogue as a New Approach in Islamic Education
}

\author{
Osman Bakar*
}

\section{Introduction}

I would like to take up the issue of the need to re-examine our traditional approaches to Islamic education. This is in view of certain fundamental changes that are taking place both in the demographic and political maps of Muslim majority countries and in the Muslim perception of Islamic education itself.

The new social reality in Muslim countries in which societal interactions between Muslims and non-Muslims are becoming both ever more extensive and intensive and, in fact, have become social necessities as in the case of Malaysia has the visible impact of making each group more aware of the presence of the other as 'neighbours'. In the light of the new social reality it becomes important for Muslims to be able to relate themselves and their religion to their non-Muslim neighbours, friends, office colleagues, fellow students, and so on, and vice versa.

The Muslim ability to portray Islam as a religion that is compatible with cultural and religious pluralism has to result from certain approaches to the understanding and practice of Islam as a contemporary way of life. Therefore, the ability in question can only be realised through a long and sustained cultural process that necessarily includes formal education as one of its core elements. It is this new demand of multi-cultural and multi-religious living that has led us to argue for a reexamination of the 'traditional' approaches to the teaching of Islam.

There are also changes in Muslim majority countries that call for new approaches to Islamic education. I am referring in particular to intellectual developments that have taken shape over the last three decades in relation to the teaching and learning of not only 'religious subjects' but also the so-called 'secular subjects'. The most important of these contemporary intellectual developments is what is popularly known as the Islamisation of knowledge movement. This movement seeks to approach the teaching and learning of all academic subjects in schools, colleges and universities from Islamic perspectives.

In the perspective of this movement, it is desirable to have an Islamic approach to all academic subjects, because the 'secular' subjects are no less relevant to Islam than the 'religious' subjects. Rightly approached - to the movement, the Islamisation of knowledge is indeed the right approach - the teaching and study of

* Prof. Dr Osman Bakar is the Deputy CEO of the International Institute of Advanced Islamic Studies (IAIS) Malaysia. 
secular subjects can, in the positive sense, have a powerful impact on the shaping of the Muslim mind so as to conform to the dictates of the Islamic world-view. Islamisation of knowledge in Malaysia has given rise to sectarian controversies and also counter-views that even question its intellectual legitimacy through their critiques of its philosophical assumptions. The core issue in the controversy is over the word 'Islamisation' itself, especially when the agenda is sought to be extended to embrace the non-Muslim communities as well.

Any attempt to re-examine past and current approaches to Islamic education has to address the issue of how Islam ought to be presented to the non-Muslim audience so as to enhance inter-religious understanding and peace. For Muslims who live together in the same society and in the same country with non-Muslims as fellow citizens and fellow countrymen, they have to really consider the interfaith dialogue approach to education not only as one that is attractive but perhaps also as the one that makes the most sense.

\section{The Meaning of Islamic Education}

What do we mean by 'Islamic education'? The answer we give to this question will determine the sort of approach we need to take in addressing issues of education in Muslim countries. It will also determine which aspects of Islamic education to be emphasised in the pursuit of dialogue between Muslims and non-Muslims. I now refer to two understandings of the term 'Islamic education' as found in contemporary Muslim societies.

As understood by the great majority of Muslims today, Islamic education refers to the teaching and learning of the so-called religious subjects which deal with the traditional religious sciences like the sciences of the Qur'ān (the traditional 'utüm al-Qur' $\bar{a} n$ ), the sciences of the Traditions of the Prophet ( 'ulüm al-hadìth), Islamic history, especially the vita (sirah) of the Prophet, and Islamic jurisprudence. Arabic, of course, is an important component of the traditional religious curriculum since it is the language of the Islamic revelation, the Qur'ān.

The other Muslim view of Islamic education, which is a minority view but which has been gaining an increasing number of adherents in recent decades, seeks to broaden and universalise the meaning of the word 'Islamic'. Islamic education is understood by them in a more comprehensive manner to include the teaching and learning of such subjects as the history and philosophy of Islamic science, Islamic civilisation, and subjects such as mathematics, sociology, economics, psychology, medicine, engineering, geography, literature and art that are universally acknowledged in modern times as secular. For this Muslim group, the traditional religious sciences together with the secular sciences constitute the total concern of Islamic education. However, they do not see the secular sciences as secular in 
nature in the sense of them having nothing to do with God or with religion. They argue that it was modern western culture that has secularised them. The very same subjects mentioned above were studied and taught by Muslims for centuries before the birth of the modern West, but these were never viewed as secular in the sense defined above.

The well-known fourteenth-century Muslim philosopher-historian, Ibn Khaldūn (d. 1406), like many Muslim scholars and thinkers before him, used the term 'ulüm al- 'aqliyyah (intellectual sciences) to refer to the category of sciences known in our modern times as secular sciences. The 'ulüm al-'aqliyyah were thus called so as to be distinguished from the 'ulüm al-naqliyyah (transmitted sciences) which coincides with much of what is identified by many Muslims today with the religious sciences. The intellectual sciences differed from the transmitted sciences neither because the former is secular and the latter religious nor because the latter is less rational and less intellectually significant than the former.

As I have argued in my Classification of Knowledge in Islam, the two categories of sciences differ from each other mainly because their respective knowledge content comes to man's possession through different ways with the transmitted sciences mainly through divine revelation (wahy) and prophetic tradition while the intellectual sciences through human intellect-reason ( $a q l$ ) and empirical studies.

The second Muslim view asserts that all branches of knowledge are connected in one way or another to religion and God and thus cannot be regarded as secular. It was fundamental changes in modern western beliefs about God, man, reality, religion, divine revelation, reason, and knowledge that brought about the secularisation of the intellectual sciences. What the second Muslim group seeks to achieve is the restoration of the 'secular' sciences to their pre-secularisation status when their knowledge content was neither seen as irrelevant to religion nor as opposed to it. They term this restoration agenda the Islamisation of knowledge.

\section{Interfaith Dialogue Approaches to Islamic Education: the Case of Traditional Religious Sciences}

If Islamic education refers to only the religious sciences then non-Muslim students and teachers are generally not involved in it. The need for interfaith dialogue, therefore, does not arise, unless the word 'interfaith' is used to mean dialogue between schools of thought or sects within the same religion. And I am not using the word in this latter sense. I prefer to use the word 'intra-Islamic' when referring to the dialogue between different schools of thought in Islam such as between the Sunnis and the Shiites.

Insofar as the teaching of the religious sciences is concerned, even when it is confined to the Muslims only, there is wisdom in adopting a 'dialogue' approach. The 
old, conservative approach is sectarian in nature, since it is based on the perspective of one madhhab (legal school) alone. I call this sectarian perspective on Islamic education madhhab exclusiveness. In this case, the sources of religious knowledge and the religious figures to be studied and taught are all selected from one madhhab, which is too restrictive.

What is preferable is madhhab inclusiveness. This is the inter-madhhab approach that seeks to understand Islam with the help of religious sources of knowledge and the views of religious figures drawn from all schools of thought. This sort of approach will help to promote inter-madhhab dialogue and thus to enhance the unity of the ummah. There is nothing to prevent Muslim political leaders and educationists from pursuing the dialogue approach to Islamic education beyond the confines of the ummah.

Inclusiveness within the ummah can be expanded so as to embrace the different 'People of the Book' (ahl al-kitāab) traditions. In practical terms, this broadening of inclusiveness would mean that the Muslims have to study the people of the book as part of their learning Islam. Since we are concerned here with the inter-religious dialogue approach to the study of Islam, there ought to be a genuine dialogue between the qur'annic position on the people of the book and the people of the book themselves. Such a dialogue would accord well with the spirit of the Qur'ān since many of its verses address the people of the book directly on a good range of issues.

There is yet another level of inclusiveness to be realised. This is the inclusiveness within humanity as a whole. Islam being a universal religion meant for the whole of humanity, its study would include the learning of the Qur'ān's global perspectives on a wide range of issues pertaining to human civilisation and human destiny as so well illustrated in many of its verses addressed to humankind. This most inclusive level of the dialogue approach to Islamic education would call for the study of Islam in comparison to other claims to world systems. In terms of knowledge sources used, it is permissible - in certain cases even encouraged - to employ sources as varied and diverse as these can be, including 'non-Islamic' and even 'non-religious' sources as long as these are not opposed to Islamic teachings.

\section{The Dialogue Approach in the Case of Universal Islamic Education}

If Islamic education is understood in its universal sense so as to be concerned with the whole body of human knowledge, including the 'ulüm al- 'aqliyyah of classical Islam, then non-Muslim students are also involved in its pursuit. The need for the dialogue approach - interfaith, inter-religious, intercultural, and intercivilisational - is even greater in this case than in the previous case when only Muslims are involved. With students comprised of both Muslims and non-Muslims, it is the last 
two of the four previously considered dialogue approaches to the study of Islam that impress upon us as the most sensible.

When viewed in the context of contemporary globalisation which has made us more and more aware of the pluralistic nature of our global community, the need for an inter-religious and intercultural dialogue approach to Islamic education becomes even more apparent.

\section{The Virtues of the Interfaith and Intercultural Dialogue Approach to Education}

The interfaith and intercultural dialogue approach to education in general and Islamic education in particular offers numerous advantages to all, Muslims and non-Muslims alike. From the point of view of Islamic education, I would like to mention here just three of the benefits. First, Muslim learning would be based on the socio-cultural reality of our own times which we Muslims encounter daily in our lives. Second, through the dialogue approach, students will come to realise the meaning of Islam as the religion of truth (din al-haqq) and consequently the meaning of Islam as the religion of knowledge. Third, Islamic perspectives on knowledge and education will become better known to the non-Muslims.

\section{Challenges to the Realisation of the Interfaith and Intercultural Dialogue Approach to Education}

The virtues and advantages of interfaith and intercultural dialogue approach to Islamic education notwithstanding, there are hurdles and challenges to their realisation that we have to face and overcome:

- The necessary preparatory knowledge for all models of inclusive education that we have discussed should be made available to and internalised by teachers and students.

- Islamic theory and practice of inter-religious and intercultural dialogue should be made available to all concerned.

- Muslim teachers have to be well grounded on Islamic teachings and intellectual traditions, especially Islamic epistemology and Islamic philosophy of education, both of which are necessary to the pursuit of excellence in learning and scholarship. 